\title{
FEASIBILITY FINANCIAL ANALYSIS OF COMMERCIAL AREA INVESTMENT AT XYZ AIRPORT
}

\author{
Luthfi Septiandy $^{1}$ and Raden Aswin Rahadi ${ }^{2 *}$ \\ ${ }^{1,2}$ School of Business and Management, Institut Teknologi Bandung, Indonesia \\ E-mail: luthfi_septiandy@sbm-itb.ac.id,**aswin.rahadi@sbm-itb.ac.id
}

\begin{abstract}
PT XYZ is enterprises that belong to West Java Provinces due to their status as regional owned enterprises. In May 2018 one of their unit XYZ Airport start the first flight to Surabaya. To increase enterprises growth, enterprises are necessary to determine the new revenue stream. The airport industry the revenue divided into two types of aero revenue and non-aero revenue. In this research focused on the non-aero sector, at the moment, XYZ has $12 \mathrm{Ha}$ area that can utilize economically to investing. Based on best practice at the predecessor, the favorable investment that can be conducted in developing the commercial area surrounding the airport. The benchmark also shows that the commercial area consists of hotel facility, outlet, retail park, and another supporting facility. Through AHP analysis, the suitable business model that firm can adopt is Joint Venture Agreement (JV) with the highest weight 37,74\% biggest among other business models Kerja Sama Pengusahaan and Build Operate Transfer. For the financial aspect, there three scenarios that differences based on the source of fund. The total investment that tenant needs in order to develop a commercial area is Rp. 491.302.150.000 otherwise for XYZ the investment is amount Rp. 188.647.712.794. From the analysis the Scenario 2 is favorable based on the result of feasibility with discounted payback period nine years, NPV amount Rp. 3.637.491.236.349. The profitability index also shows that investment is profitable over the requirement $(>1,00)$ also the internal rate of return higher than cost of capital with $27,68 \%$. For sensitivity analysis, there four parameters as the basis to calculate, and the analysis shows interest rate with swing $10 \%$ from basis point resulting huge deviation from NPV $-17,26 \%$.
\end{abstract}

Keywords : Investment, Feasibility, Partnership, Decision Making, Commercial Area

\section{INTRODUCTION}

Infrastructure is one of the essential parts for the countries; the wealth of nations can measure by their development. According to (APBN, 2018), infrastructure sector spends 410,4 Trillion Rupiah or 18,45\% from whole portion amount 2.220,7 Trillion rupiah. Transportation is part of the infrastructure, XYZ Airport located in Majalengka, West Java included the national strategic project for Indonesia. The objective of this investment is to reduce and distribute the contingency at Soekarno-Hatta International Airport (SHIA), according to (World Airport Codes, 2018)it the busiest airport at 17th position in 2016 with total passenger 63,015,620 and the grows $8,3 \%$ from the previous year.

Besides those issues, XYZ Airport also initiates to became the embarkation of Hajj Pilgrim for the following year. XYZ Airport initiated in 2003, and the feasibility study has been carried out at the time, West Java Government was able to fund this project with their budget (APBD). However, for almost ten years, the construction work has not executed due to the permit administration already expired. At 2014 the construction work begins with fund source Government Cooperation with Business Entities (KPBU) and total investment amount Rp.4,916 Trillion, and in the middle of 2018, the project finished. The problem occurs when the actual traffic and the partnership airlines are below the forecast, so it has to be some strategy to leverage and attract the potential airlines, one of best practices develops the supporting infrastructure like commercial area, hotel, retail, etc. surround the airport. 


\section{LITERATURE REVIEW}

Literature review in a particular research study is one of the essential element from the whole sequences of research method. According to (Creswell, 1994) stated that "literature review has several objectives which are informed to the readers the past research result" that closely related to current research. These are the research related to author research:

1) "Financial Assessment and Risk Analysis for Airport Hotel” by Hrönn Skaptadóttir (2016)

In his report, Hrönn Skaptadóttir determines the future investment of Keflavik Airport in Iceland. Due to the tourist industry in Iceland is seasonal, the high season is over the summertime in June - August. The objective of this research is to analyze three various cases that having a different approach to building \& operating. The result at case 1 generate 851 Million Iceland Krona (MISK) for 20 years, and Modified Internal Rate of Return (MIRR) is 11,3\% otherwise for case 2 the NPV and MIRR respectively are -70 MISK and 9,9\% and the last case resulting 674 MISK for NPV and 17,0\% of MIRR. The company policy of return for equity was $10 \%$, which means only case 1 and 3 are acceptable.

2) "Mostar Airport Strategic Development Model" by Andrija Vidovic, Tomislav Mihetec and Daniel Galic (2017)

Andrija Vidovic and his colleague researched of Mostar Airport that belongs to Bosnia and Herzegovina government. Since 2010 the traffic result after 10-year post-war traffic stagnation, even though in recent years the number of traffic are doubled. Based on the current condition, the firm should develop a particular strategy to fulfill customer needs. The goal of this research is to develop a strategic model and traffic forecast that may be suitable for all airport in Bosnia-Herzegovina. Based on the analysis, the result is Mostar Airport utilize the current infrastructure into business object beside it for long-term develop non-aviation activities and increase revenue. The demand itself show traffic growth between 8 to $10 \%$ until 2025.

3) “Financial Feasibility Study of Mix Use Building Area Investment Plan” by Nurul Sandy Putri (2018)

Nurul Sandy analyze the agreement between PT KLM and PT Wijaya Karya of mix-used development, the period of the consortium are 30 years. Based on these issues, she evaluates and calculates the NPV, IRR, and payback period. To minimize the uncertainty, she also conducts the 53 variable sensitivity and three scenarios; moderate, pessimistic, and optimistic. Based on the analysis, the result is NPV amount 65,4 Billion IDR, IRR 12.92\% (above WACC $=11,51 \%$ ) and 26 payback period. The sensitivity also shows four most variables that affects, which are the total investment, operational hotel, amusement park, and compensation.

4) "Financial Feasibility Study And Public-Private Partnership Funding Alternatives For The Development Of New Port In Bulungan District, North Kalimantan Province” by Rehan Aufa Fakhri (2018)

North Kalimantan Province has potential as a gate of export-import activity, Tanjung Palas Timur SubDistrict has 5.000 ha land as investment one of it is an international port. Rehan Aufa takes this issue to determine the financial feasibility of the project and distinguish the kind of contract with Analytical Hierarchy Process (AHP). Based on the analysis, the NPV generate over 1,2 trillion IDR with the internal rate of return above the cost of capital and payback period are 13 years. The suitable contract based on AHP is Built, Operate and Transfer.

\subsection{Unit of Analysis}

In two decades, airports had transformed from being public sector infrastructures providers into sophisticated business-oriented service providers (ICAO, 2013). It occurred as a result of emergence among airport competitiveness. In the airport industry, the revenue divided into two categories: aeronautical charges and non-aeronautical or commercial revenues. Aeronautical charges are levied on airlines by the airport operators for using their facilities and include landing and apron charges and passenger fees, and Table 1 shows the difference between two source revenue. 
Table 1. Airport Revenue Sources.

\begin{tabular}{|l|l|}
\hline \multicolumn{1}{|c|}{ Aeronautical } & \multicolumn{1}{|c|}{ Non-Aeronautical } \\
\hline Landing fees & Concessions \\
\hline Passenger fees & Rents \\
\hline Aircraft parking fees & Direct sales (shops, catering) \\
\hline $\begin{array}{l}\text { Handling fees (if the airport operator provides } \\
\text { handling) }\end{array}$ & Car park \\
\hline Other aeronautical fees (ATC, lighting, airbridges, etc.) & Recharges (gas, water, utility) \\
\hline & $\begin{array}{l}\text { Other non-aero revenue (consultancy, business } \\
\text { services, property management, etc.). }\end{array}$ \\
\hline
\end{tabular}

Sources: Graham A (2007)

\subsection{Business Issue}

In Indonesia almost whole airport is belonged and operating by State Owned Enterprises known as Angkasa Pura, only two that owned by regional authority first is Hang Nadim International Airport and XYZ Airport that owned by West Java Province. However, since the enterprise not yet able to operate the airport, they asked Angkasa Pura to carried out the airport operation with a certain agreed period. Based on that agreement, the company should share its total revenue to Angkasa Pura. Besides that they also pay the human resource from Angkasa Pura.

Currently, the portfolio business of $\mathrm{XYZ}$ are airport operation, and tenant inside the terminal that operating since May 2018 with the first route is Majalengka-Surabaya. As times goes by the number of airlines partnership also will increase due to the potential market that will capture. Nevertheless, besides the aeronautical revenue, the company have the plan to force the non-aeronautical revenue to get sustainable business. The concession is part of non-aeronautical revenue, and it generated from commercial activity within terminals and also on airport land. Many airports generate a much higher proportion of their income from concession activities than from aeronautical operations.

\subsection{Problem Statement}

Based on that description and explanation, there are some question can be formulated as follows:

a) Is the commercial area investment feasible as financial perspective?

b) What is the suitable business schemes of the commercial area?

\section{METHODOLOGY}

The methodology is the technique of obtaining, organize, and processing data (Polit \& Hungler 2004:233). Methodology decision depends on the nature of the research question, and it can be considered to be the framework of correct scientific decision (Mouton \& Marais 1996:16). The methodology of this research can be see in Figure 1.

Based on the figure below the flow divided into four phases, the 1st phase is the preparation that the activity consists of study literature from publication, journal, previous research and also determine the particular location as a controlled study in this case author choose PT.XYZ as the firm. The next phase is collecting data, and the author takes the primary data directly from the firm and the secondary data based on interview and internet research. The 3rd phase is to identify, calculate, and analyze the data given to resulting the outcome like the current business situation, feasibility assessment, and decision making 


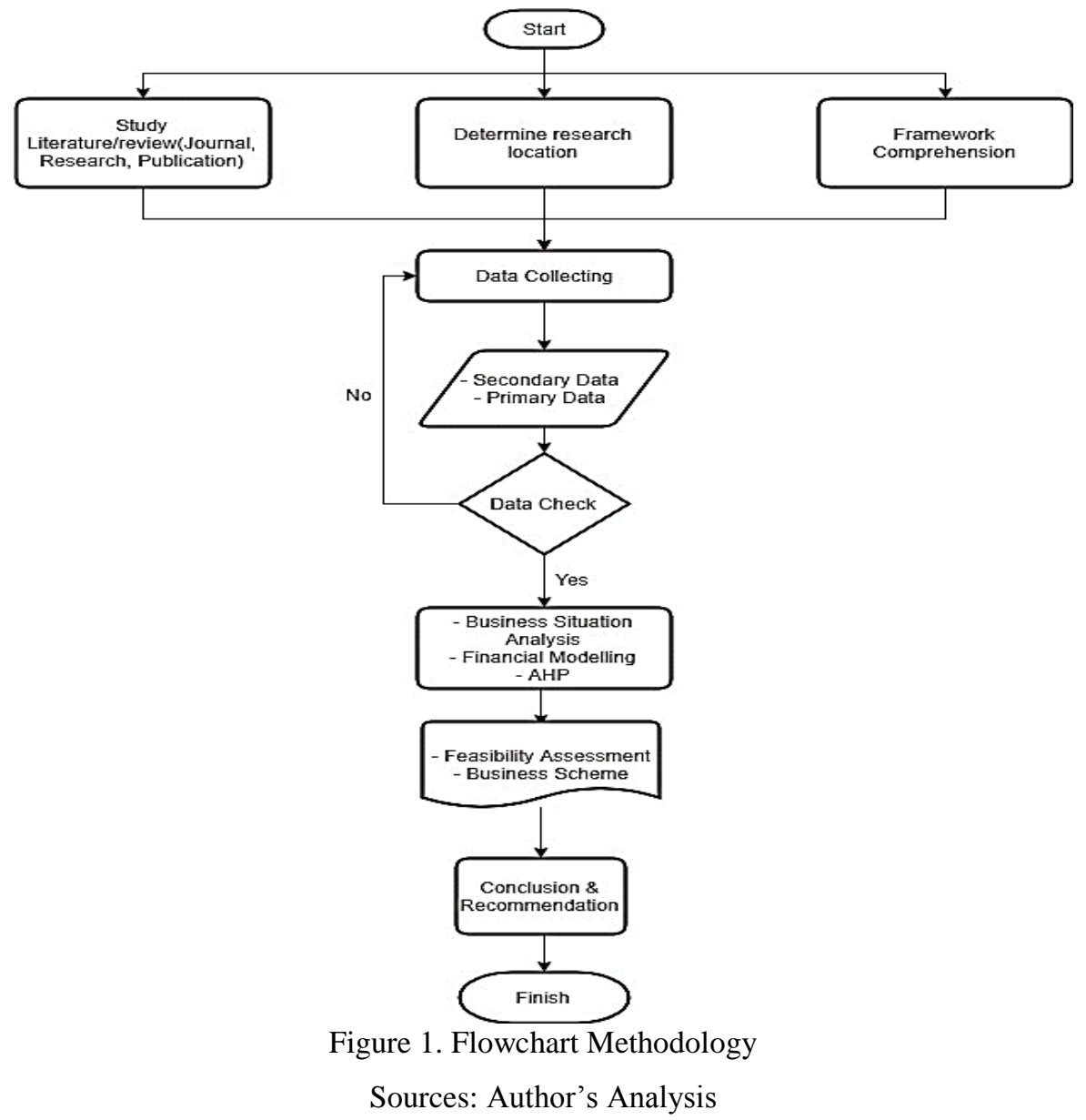

\subsection{Explanation of Conceptual Framework}

Investment is a result of the company's strategy. Thus strategy itself is the set of activity that decision maker takes to outperform the company's rival and achieve superior profitability. Since the goal of the company is to maximize shareholder value, so they have to plan and execute the strategy appropriately.

\subsection{Business Situation Analysis}

A generic company strategy emphasizes the specific management game plan for competing successfully its positive efforts to position itself in the marketplace, please customers, deny competitive threats, and achieve a particular kind of competitive advantage. The probability of the firm in the same industry that applied specific competitive strategy is less. Nevertheless, the unique one competitive approach from one and another are base on two most significant factors whether a company market target is broad or narrow, whether the company is pursuing a competitive advantage linked to lower costs or differentiation. To identify Business Situation Analysis divided into two types external and internal, techniques to carry out external analysis are PESTEL and Five Forces Porter, on the other hand, for internal analysis, SWOT is suitable. These are the explanation for each technique and tools.

\subsection{PESTEL}

Every company operates a large macro environment that consists of 6 principal components: political factors, economic condition, sociocultural forces, technological factors, environmental factors, and legal/regulatory requirements. Each of those components has a potential impact on the firm and competitive environment, although some are likely to have a more critical effect than others. This tool often has a term known as PESTEL analysis acronym that serves as a reminder of 6 components (Thompson, 2016). 


\subsection{Five Forces Porter}

Beside of PESTEL the standard tools for diagnosing the principal competitive pressures in the market is 5 Forces Porter Analysis (Thompson, 2016), this tool holds that competitive pressures on the company within an industry from 5 sources. These include competition from rival sellers, competition from potential new entrants to the industry, competition from producers of substitute products, supplier bargaining power, and customer bargaining power.

\subsection{SWOT}

In evaluating the overall company situation, the main question is that the company is in a position to pursue attractive market opportunities and defend against external threats to its future well being. The most tools for carried out this examination is widely known as SWOT analysis and is named because of consist of a company internal strengths and weakness, then external threats and market opportunities.

\subsection{Financial Analysis}

Investment is one of essential activity for the company to sustain in the industry, and it represents sizable outlays of funds that commit a company to take some action. Subsequently, the company has to analyze and select it the appropriate long-run investment. The standard tools to process and evaluate it called as Capital Budgeting Technique (Lawrence J Gitman, 2015). The process of it consists of 5 distinct: proposal generation, review and analysis, decision making, implementation, and follow up.

\section{A. Cost of Capital}

According to (Spencer, 1998) Cost of Capital is the minimum required rate of return which a company requires as a condition for undertaking an investment. Investment with a rate of return above the cost of capital will increase the value of the firm; otherwise, if the project rate return below the cost of capital, it will decrease firm value. There are three sources to fund investment project debt, equity, and preferred stock.

\section{a) Cost of Debt}

Cost of debt is the external financing cost associated with new funds raised long-term borrowing through creditor/bank. Typically the funds are raised through the sale of corporate bonds. For this source fund, the common tools known as after-tax cost of debt. To determine the firm net cost of debt, it has accounted for tax saving created by debt and solves for the cost of long term-debt on after-tax basis. The after-tax cost of debt $r_{\mathrm{i}}$ can be calculated by multiplying the before-tax $\cos t r_{\mathrm{d}}$, and 1 subtracts the tax rate, $T$ as the following equation below: $r_{i}=r_{d} \times(1-\mathrm{T})$ Equation (1)

\section{b) Cost of Equity}

Cost of common stock as part of the cost of equity, it is the rate at which investors discount the expected common stock on the firm to determine its share value. The method is used to measure the cost of equity is Capital Asset Pricing Model (CAPM). The formula to determine CAPM can be see in Equation 2.

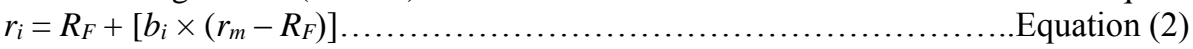

where:

$r_{i}=$ required return on asset $i$

$R_{F}=$ risk-free rate of return, from Indonesia can be captured from IPBA Government bond or BI 7 day repo rate

$b_{i}=$ beta coefficient or index nondiversifiable risk for asset

$r_{m}=$ market return (IDX stocks)

\section{c) Weighted Average Cost Capital}

Since firm not only funding their investment from a single source, it possible to financing with others. To determine those total costs of capital, it can calculate with Weighted Average Cost Capital (WACC), it represents the expected average future cost of capital over the long term. It multiplies the individual cost of each source of financing by its portion in the firm capital structure and sums the weighted values. To calculate the WACC can use equation as follow:

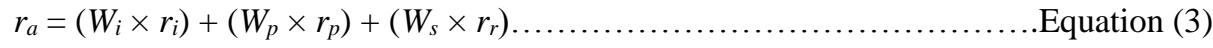


where:

$W_{i}=$ proportion of long-term debt in the capital structure

$W_{p}=$ proportion of preferred stock in the capital structure

$W_{s}=$ proportion of common stock equity in the capital structure

\section{B. Feasibility Assessment}

Every investment may generate the profit or loss for the company, so the analyst has to evaluate and assess the investment, whether acceptable or not. There are several parameters to measure the investment such as NPV, IRR, Profitability Index, and Payback Period.

\section{a) NPV}

The typical method to analyze investment project known as Present Net Value (NPV). The principle of NPV is when the investor spends their fund to a particular project, and they tend to expect a positive return for period time investment. NPV determine by subtracting an initial project investment $\left(\mathrm{CF}_{0}\right)$ from the plan of its cash flows $\left(\mathrm{CF}_{\mathrm{t}}\right)$ discounted at a rate equal to the firm cost of capital $(r)$. Equation 4 shows the formula of NPV.

$\mathrm{NPV}=$ Present Value of Accumulated Cash Flow - Initial Investment

$\mathrm{NPV}=\sum_{t=1}^{n} \frac{\mathrm{CFt}}{(1+r) t}-C F 0$ Equation (4)

NPV is decision-making tools, the decision criteria are as follows:

$>$ If the NPV $>0$, accept the project

$>$ If the NPV $<0$, reject the project

\section{b) Profitability Index}

The modify of the NPV called as Profitability Index (PI). For an investment that has an initial cash flow, the PI is equal to the present value of cash inflows divided by their initial cash outflow. To calculate PI can use formula as follow:

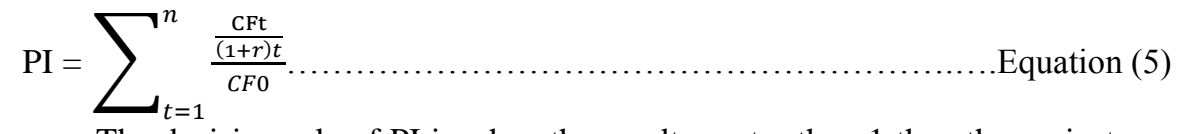

The decision rule of PI is when the result greater than 1 then the project are acceptable. However, particular industries have a minimum requirement for these tools.

\section{c) Internal Rate of Return}

The internal rate of return is the discount rate that equates the NPV of an investment opportunity with 0 amount. It is the rate return that the firm will earn if it invests in the project and receives the given cash inflows. To calculate IRR can use equation 6.

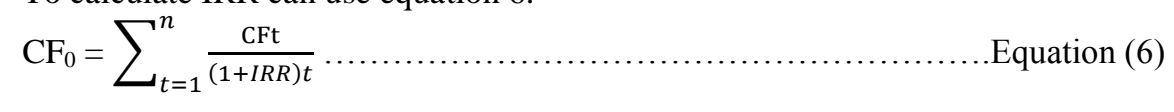

\section{d) Payback Period}

The payback period is how long investor will get the break-even for it investment from cash inflows. However popular in investor terms the payback period generally viewed as a simple capital budgeting technique, because it does not explicitly consider the time value of money. At the moment there is the modification of payback period called a discounted payback period. The calculation same with the previous but the cash inflows already discounted to present value.

When the payback period is used to make accept-reject condition, the following decision criteria apply:

$>$ If the payback period is less than the maximum acceptable payback period, take the project

$>$ If the payback period is higher than the maximum adequate payback period, reject the project 


\section{Free Cash Flow and Terminal Value}

\section{1) Free Cash Flow}

Free cash flow represents the cash available to the investor, the providers of debt (creditors) and equity (owners) after the firm has met all operating needs and paid net investments in fixed asset and current assets. Equation 7 shows the formula of how to calculate FCF.

$\mathrm{FCF}=$ NOPAT $($ Net Operating Profit After Tax $)-$ Net Fixed Asset Investment + Depreciation Equation (7)

\section{2) Terminal Value}

Terminal cash flow is the cash flow resulting from termination and liquidation of a project at the end of its economic life. It represents the after-tax cash flow exclusive of operating cash inflows, that occurs in the final year of investment. To calculate terminal cash flow can be seen in equation 8 .

Terminal Value $=\frac{\mathrm{FCFT} *(1+\mathrm{g})}{\mathrm{r}-\mathrm{g}}$ Equation (8)

Where:

$\mathrm{FCF}_{\mathrm{T}}=$ free cash flow at the end of the investment period

$r \quad=$ cost of capital

$g \quad=$ growth assumption (GDP growth, Industry Growth, sustainable growth rate, etc.)

\subsection{Analytical Hierarchy Process Framework}

Decision making, for which collect to gain information has become a mathematical science today (Figuera et al.,2005). It formalizes the thinking the people use so that, what they do to make better decisions is transparent in all its aspects. Decision making involves many criteria and subcriteria used to rank the option of a decision. The criteria might be intangible and have no quantified to serve as a direction to rank the option and creating priorities for the criteria themselves to value the priorities of the option.

To determine a suitable decision in an organized way to generate priorities need to decompose the decision into the steps as follow:

a. Define the problem and identify the kind of knowledge sought

b. Structure of the decision hierarchy from the top with the goal of choice, then the goals from a broad perspective, through the intermediate levels to the lowest level.

c. Construct a set of pairwise comparison matrices; each element in an upper level is used to compare the features in the level immediately below.

d. Use the priorities obtained from the comparisons to weigh the priorities in the level immediately below, conduct this for every element. Then for each component in the level add it is weighted value \& obtain it is as overall. Continue the process of weighting until the final priorities of the option obtained.

When making the comparison, it needs a scale of numbers that indicate how many times more important or dominant one element over others element concerning the criterion (Saaty, 2008). Saaty develop the range of AHP itself, for example, How many times more, or how strongly more is that drink consumed in the US? One of respondent select 5 in the (coffee, wine) position meant that coffee consumption is five times rather than wine consumption. It also automatic reverse the other side that $1 / 5$ is what one needs to use in the (wine, coffee) position. Table 2 shows the fundamental scale of absolute numbers.

Table 2 The fundamental scale of absolute numbers

\begin{tabular}{|c|c|c|}
\hline $\begin{array}{c}\text { Intensity of } \\
\text { Importance }\end{array}$ & Definition & Explanation \\
\hline 1 & Equal importance & Two activities contribute equally to the objective \\
\hline 2 & Weak or slight & $\begin{array}{c}\text { Experience \& judgment slightly favor one over } \\
\text { another }\end{array}$ \\
\hline 3 & Moderate importance & \multirow{2}{*}{$\begin{array}{c}\text { Experience \& judgment strongly favor one over } \\
\text { another }\end{array}$} \\
\hline 4 & Moderate plus & Strong importance \\
\hline 5 & \multicolumn{2}{|c}{ Source: (Saaty, 2008) } \\
\hline \multicolumn{2}{|c}{}
\end{tabular}


When developing AHP also need to determine consistency, based on the framework, the ratio designed in such a way that values of the ratio exceeding 0,10 are indicating of inconsistent judgments. One element of AHP that also important is Random Index, which is the consistency index of a randomly generated pairwise comparison matrix. The Random Index depends on the number of elements compared and effect through the value as follow:

Table 3 Random Index

\begin{tabular}{|c|c|c|c|c|c|c|c|c|c|c|}
\hline $\mathrm{n}$ & 1 & 2 & 3 & 4 & 5 & 6 & 7 & 8 & 9 & 10 \\
\hline $\mathrm{RI}$ & 0,00 & 0,00 & 0,58 & 0,90 & 1,12 & 1,24 & 1,32 & 1,41 & 1,45 & 1,49 \\
\hline
\end{tabular}

\section{RESULTS AND DISCUSSION}

\subsection{Business Situation Analysis}

Since the business process of XYZ Airport is inter corporation, so the approach suitable for business situation is with Business to Business (B2B) approach. These are the result and analysis of those methods.

\section{A. PESTEL}

Every company operates a large macro environment that consists of 6 principal components: political factors, economic condition, sociocultural forces, technological factors, environmental factors, and legal/regulatory requirements. Each of those components has a potential impact on the firm and competitive environment, although some are likely to have a more critical effect than others. This tool often has a term known as PESTEL analysis acronym that serves as a reminder of 6 components.

Political factors that would affect PT XYZ business is the election in 2019 for legislative and executive. After this event, mostly all of the government policy will change due to the interest of candidate during the campaign. The $2^{\text {nd }}$ component is the economic condition, according to the inflation target in 2019 until 2021 is $\pm 3 \%$, which the number is quite small and less volatile. For the conversion rate between dollar to rupiah according to is \pm 15.000 , at the moment GDP growth of Indonesia is 5\% lower than Vietnam with $6,81 \%$ and Philipines with 6,7\% but higher than Singapore with 3,5\%.

Indonesia consists of thousand islands from west to the east pacific-hindia ocean with various race, religion, and language. According to the average age of Indonesia is 28,6 years which productive compare to others, the projection population at 2045 is \pm 290 million, and at 2050 for $60 \%$ population will live in the city. The shifting from conventional into digital already implemented like e-money and e-commerce, at the moment, the poverty rate of Indonesia is $9,82 \%$ the lowest since 1999.

In the technological side indicate that human position substitute by machine, robot, and artificial intelligence. In the construction sector, there is a technology of top-down method, at the past when constructing the building, the step is from the bottom, but now with the new method, it can reduce the time. The concrete technology is also developing from in-cast concrete into precast concrete. Since Indonesia is a tropical country with only two seasons rainy and dry, which will affect the construction works. Even though the last colossal earthquake occurred in 1990 but the land movement also should consider due to the effect of disaster. The last aspect is law, and regulatory, Indonesia has \pm 42.000 of law, Undang-Undang, regulation, and policy, and many of them are counterfeit. The bureaucracy also complicates in order of investment. However, the government develops an institution that handles of simple investment single door to reduce the process.

\section{B. 5 Forces Porter}

Beside of PESTEL, the standard tools for diagnosing the principal competitive pressures in the market is 5 Forces Porter Analysis, and this tool holds that competitive pressures on the company within an industry from 5 sources. These include competition from rival sellers, competition from potential new entrants to the industry, competition from producers of substitute products, supplier bargaining power, and customer bargaining power. Figure 2 shows the result of the 5 Forces Model Analysis. 


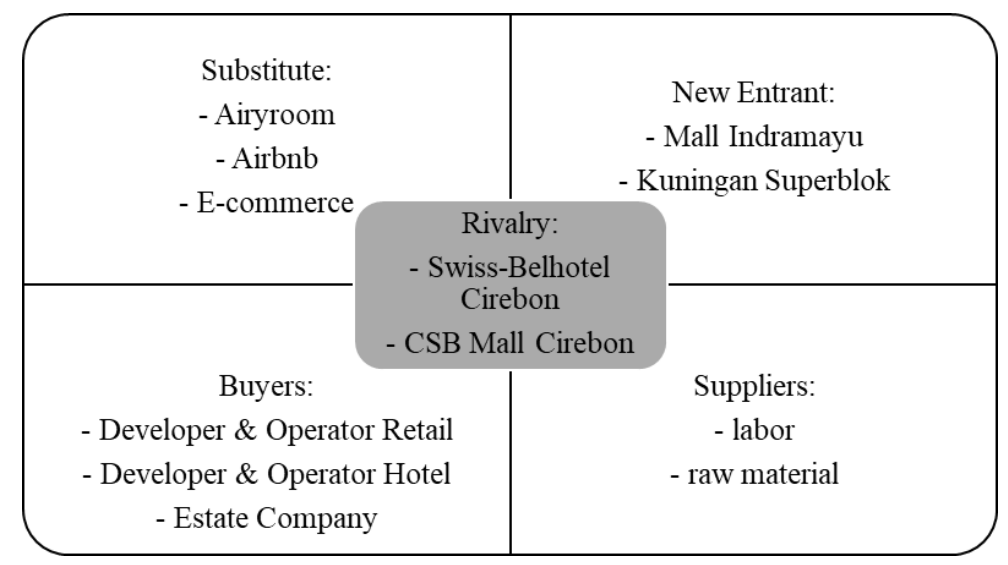

Figure 2. Result of 5 Forces Porter XYZ Investment

Source: Author's Analysis, 2018

According to the figure above the rivalry of PT XYZ is Swiss-Belhotel and CSB Mall, both of them located in Cirebon. Swiss-Belhotel is operator and developer from overseas that have branch around the world with four class hotel. However, the distance between the airport and the hotel is quite far so it can be taken as an advantage for XYZ to develop hotel inside the commercial area. Meanwhile, CSB Mall is the biggest supermall in Cirebon with one-stop shopping center concept. They offer various food and beverage, retail with department store and supermarket to fulfill the family necessity.

In the customer side, the buyer well informs about the current condition of the passenger, and they tend to wait for the situation of the airport to settle instead take a risk as a pioneer to invest. So the firm has challenged to convince them that the demand will increase as much as the following time. The next forces are supplier, the competencies and capabilities of labor are crucial at the time because they had to construct the infrastructure, raw material availability also the key through the construction phase.

Kuningan Region which near the airport had a plan to develop superblock at the center of the city. This project fully supported by the local government because they did not pay anything due to the investor responsible all of the funding. Not only develop supermall, the investor also to build a central business to activate local economic activity. The next potential new entry beside Kuningan Superblock is Indramayu Mall, this project starts the construction in April 2018 and expects finished in January 2019. Currently, there is some national tenant that already join the investment such as Matahari, Super Indo, Cinemaxx, Pizza Hut, etc.

Besides the retail industry in 2020, some area also will develop a hotel to support the business as a new revenue stream. With the business disruption from e-commerce like Zalora, Zilingo, Berrybenka, etc. will substitute the current business of conventional. As we know the disruptive business eliminate the process and cost of conventional business, it will jeopardize the investment.

\subsection{Income Statement Projection}

According to (Merrill Lynch, 1997), the income statement can be thought of more like a motion picture, and it shows how much the corporation earned or lost during a specific time. Since this research conduct modeling of financial so the income statement will be like projection. The income statement is the mixed up between all of revenue and cost, so the income statement for both side as followss. Table 4 shows the Income Statement Projection for a tenant. 
Table 4. Income Statement Projection for Tenant Side

\begin{tabular}{|l|r|r|r|r|r|}
\hline Alternative 1 (Full Equity) & 2030 & 2031 & 2032 & 2033 & 14 \\
\hline & 11 & 12 & & & \\
\hline & & & & & \\
\hline
\end{tabular}

Based on Table above the huge expenses came from cost of revenue and renting land to the landowner, however after operating profit, the deduction from tax also state as massive portion of the cost. Nevertheless, the margin of net income toward gross revenue is almost half, which considered profitable.

\subsection{Capital Budgeting}

Feasibility Assesment is the end of the financial aspect of the investment because based on this step, the decision maker can decide which the project are accepted or neither. It consists of several parameters for the basis; the parameters are payback period, discounted payback period, net present value, profitability index, and IRR.

Those parameters will elaborate sequentially as follow:

a) Payback Period

Payback period (PBP) is a tool to determine how long the project/investment is break even compared to their initial investment. It sums the initial investment and subtract with the future cashflow during period. The calculation of the payback period as follows:

Cash Flow $7^{\text {th }} \quad=$ Rp. 104,21 billion

Cumulative CF $6^{\text {th }} \quad=$ Rp. $(87,95)$ billion

Range PBP $\quad=6$ to 7 years

PBP $\quad=6+(=6,93$ years

Based on the calculation above the PBP is almost seven years. From this calculation, the decision maker can determine how long the duration of the agreement with the partner. Normally the period of the agreement is twice from the payback period because at the time the partner starts to generate profit.

b) Discounted Payback Period

The discounted payback period is similar to the payback period, when PBP does not consider the time value of money DPBP conduct it. As we know that cash flow from PBP is the future CF, it was discounted to present value, so the DPBP ideally is the most near the actual condition. The calculation of DPBP can be seen as follow:
PV CF $9^{\text {th }}$
$=$ Rp. 65,99 billion
Cumulative PV CF $8^{\text {th }}$
$=$ Rp. $(52,65)$ billion
Range PV PBP
DPBP
$=8$ to 9 years
$=8+(=8,80$ years

Based on the calculation, the discounted payback period is longer than the payback period with almost nine years, and the investment will break even. So the agreement due to analysis is 16 years. 
c) Net Present Value

Net Present Value (NPV) is the difference between the initial value of the investment and the total of discounted cash flow over the period. So the calculation of NPV as follows

$$
\begin{array}{ll}
\text { Initial investment } & =\text { Rp. } 491,302 \text { billion } \\
\text { Cost of capital } & =6,79 \% \\
\text { PV CF } & =\text { at Table } 3.17 \\
\text { NPV } & =\ldots . .+(-491.302 .150 .000=\text { Rp. 4.506.528.827.997 }
\end{array}
$$

Based on calculation, the NPV for the tenant use Scenario 1 is worth Rp. 4,5 Trillion, which higher than 0 and the investment is acceptable.

d) Profitability Index

Profitability index (PI) is an index to determine how much the project/investment are profitable. PI 1,0 is the lowest acceptable measure on the index. As the value of PI increases, it will affect the attractiveness of the investment. The calculation of PI is simply NPV divided the initial investment. The calculation of PI can be seen as follow:

NPV scenario $1=$ Rp. 4,5 trillion

Initial investment $=$ Rp. 0,491 Trillion

PI $\quad=10,17$

According to calculations above the PI of the investment is 10,17 and it higher than 1,0 , so the project is strongly acceptable.

e) Internal Rate of Return

Internal rate of return (IRR) is a discount rate that makes NPV of total cash flow equal to zero. The acceptable project/investment is if the IRR higher than the cost of capital. The IRR of the project in

\begin{tabular}{|c|c|c|c|c|c|}
\hline Alternative 1 & $\mathbf{0}$ & 1 & 2 & 3 & 4 \\
\hline \multicolumn{6}{|l|}{ FREE CASH FLOW } \\
\hline Cash Flow & $(491.302 .150 .000,00)$ & - & $76.396 .393 .509,43$ & 69.768.947.301,92 & $77.369 .044 .182,74$ \\
\hline Cash Flow (in Billion) & $(491,30)$ & - & 76,40 & 69,77 & 77,37 \\
\hline WACC & $6,79 \%$ & & & & \\
\hline PV of Cash Flow & $(491.302 .150 .000,00)$ & - & $66.995 .050 .771,72$ & $57.295 .031 .895,49$ & $59.498 .629 .009,87$ \\
\hline Payback Period & 6,93 & & & & \\
\hline Discounted Payback Period & 8,80 & & & & \\
\hline Net Present Value & Rp4.506.528.827.997,81 & & & & \\
\hline Profitability Index & 10,17 & Profitable & & & \\
\hline IRR & $24,65 \%$ & Acceptable & & & \\
\hline
\end{tabular}
scenario 1 is $24,65 \%$, which project is acceptable because of it higher than the cost of capital $=6,79 \%$.

The calculation model for capital budgeting can be seen at Table 5 below.

Table 5. Capital Budgeting Model for Alternative 1.

Source: Author's Analysis, 2018

According to the table above the result of Alternative 1 for the tenant, side stated the investment is feasible, acceptable, and profitable. If the tenant using this model they can break even the investment in nine years (considered time value of money) the NPV also resulting huge amount Rp. 4,506 trillion it almost nine times the amount from the initial investment (with period 15 years). Another alternative for both sides can be seen as follow: 
Table 6. Summary of Feasibility Assessment

\begin{tabular}{|c|c|r|r|r|r|r|}
\hline \multicolumn{2}{|c|}{ Feasibility } & $\begin{array}{c}\text { Payback Period } \\
\text { (Years) }\end{array}$ & $\begin{array}{c}\text { Discounted Payback } \\
\text { Period (years) }\end{array}$ & Net Present Value (IDR) & $\begin{array}{c}\text { Profitability } \\
\text { Index }\end{array}$ & IRR (\%) \\
\hline \multirow{4}{*}{ To Tenant } & Alternative 1 & 6,93 & 8,80 & Rp4.506.528.827.998 & 10,17 & $24,65 \%$ \\
\cline { 2 - 8 } & Alternative 2 & 7,26 & 8,98 & Rp3.637.491.236.349 & 15,81 & $27,68 \%$ \\
\cline { 2 - 8 } & Alternative 3 & 6,91 & 8,85 & Rp4.444.218.038.763 & 12,31 & $25,98 \%$ \\
\hline \multirow{3}{*}{ To XYZ } & Alternative 1 & 12,44 & 14,04 & Rp1.218.979.470.894 & 7,46 & $21,41 \%$ \\
\cline { 2 - 8 } & Alternative 2 & 12,60 & 14,04 & Rp1.214.610.064.836 & 7,44 & $21,34 \%$ \\
\cline { 2 - 8 } & Alternative 3 & 12,50 & 14,04 & Rp1.217.231.708.471 & 7,45 & $21,38 \%$ \\
\hline \hline
\end{tabular}

Source: Author's Analysis, 2018

Based on the table above whole Scenario resulting that investment is feasible from the financial perspective; however, for the XYZ, the result quite similar due the source of fund is coming from equity. Nevertheless, the tenant also should consider the credit risk if they use the debt as a source of investment, but the pros of using debt is to leverage the performance.

\subsection{Sensitivity Analysis}

According to Investopedia, sensitivity analysis also referred to as what-if analysis is a tool to assumpted the result of optional given from a specific range of variables. In this research, the author selects some parameter as the basis for sensitivity analysis that affects to feasibility assessment. The dependent value of this analysis is Net Present Value so that the parameter will calculate how much to the NPV. Graphic 2 shows the result of the sensitivity analysis for scenario 3 .

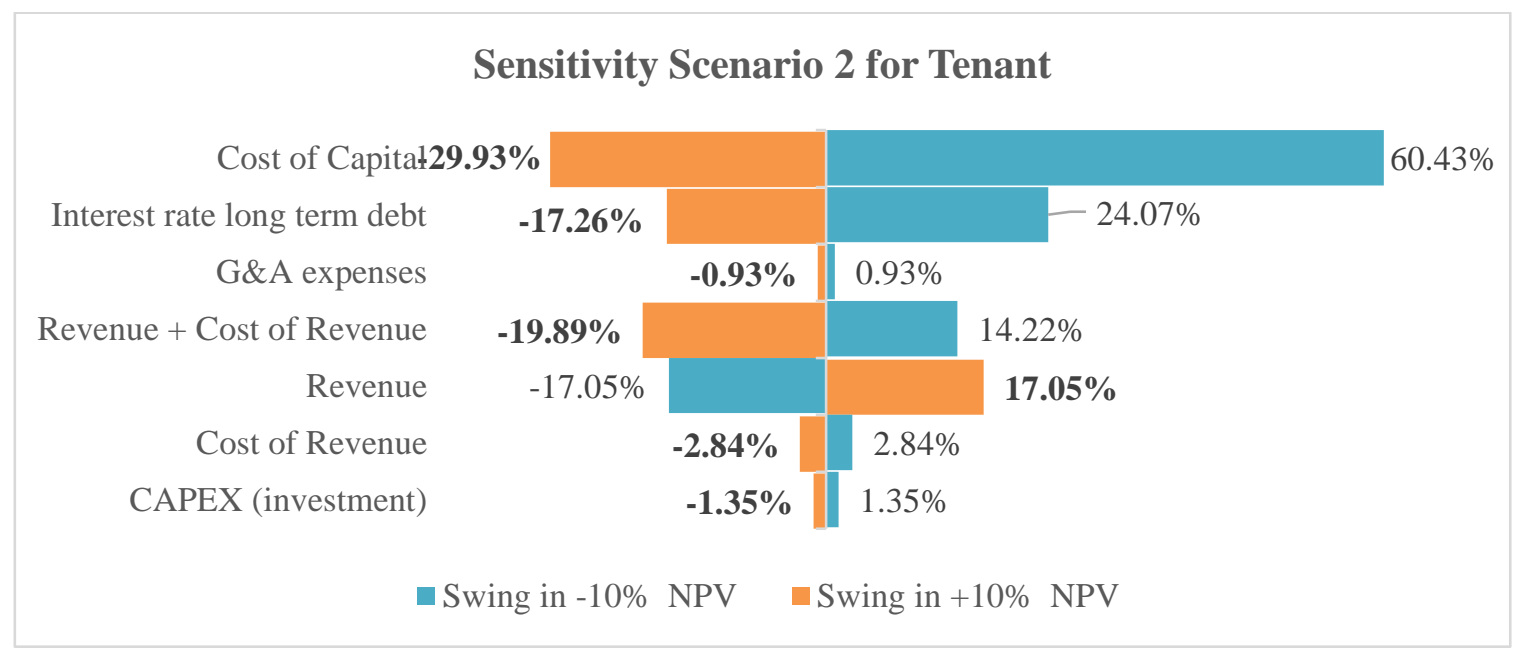

Figure 3 Sensitivity for Tenant Scenario 2

Source: Author's Analysis, 2018

The $10 \%$ swing of this analysis conducted for both sign (+/-) the parameter of sensitivity is consist of Cost of Capital, Interest debt rate, G\&A Expenses, Revenue, Cost of Revenue and CAPEX (investment). Those parameters used due to the amount toward model and most likely will affect the investment. Based on the table above the four parameters resulting comparable value, the only cost of capital and long term debt that affect the different amount. The ultimate result can found for the cost of capital when the number swing $-10 \%$ the NPV will increase $60,43 \%$ from basis point.

\subsection{Analytical Hierarchy Process}

Due to the financial condition and need, much investment at beginning XYZ can distribute the load with the various business scheme that can be used. Nowadays, there is innovation to public service facility Public Private Partnership are the typical model. According to PP No.1 Tahun, 2008 PPP are investment cooperation between the Government Investment Agency and Business Entity and or government with the private company. Type of PPP are various like Joint Venture Agreement, Build Operate Transfer, and Kerja Sama Pengusahaan (KSP). 
To determine which one the suitable business scheme to this investment can use the Analytical Hierarchy Process (AHP). The goal of AHP itself measures the alternative of choices based on the criterion. The criterion for this particular divide into 4: operational, Finance, Legal, and Risk. Each criterion has the weight and priority, and the value results from stakeholder that relate to these circumstances.

Table 7. Matrix Alternative and Criterion

\begin{tabular}{||l|l|l|l|l|ll||}
\hline & Operational & Finance & Legal & Risk & Criterion \\
\hline JV & 0,62 & 0,13 & 0,33 & 0,11 & Operational & 0,441 \\
\hline KSP & 0,14 & 0,51 & 0,52 & 0,31 & Finance & 0,256 \\
\hline BOT & 0,24 & 0,36 & 0,14 & 0,58 & Legal & 0,164 \\
\hline & & & & & Risk & 0,139 \\
\hline
\end{tabular}

$\mathrm{JV}=37,74 \%$
$\mathrm{KSP}$
$\mathrm{BOT}$

Based on calculation and analysis, it can distinguish that the Joint Venture Agreement is the best recommendation among others. However, decision making depends on the stakeholder of the firm.

\section{CONCLUSIONS}

According to analysis and evaluation from the previous chapter, the current business situation analysis used External and Internal Analysis. The external utilize tools of PESTEL and Five Forces Porter that the investment can result in high profitability if the obstacle can minimize. Otherwise, the internal analysis used the SWOT tools resulting in the investment had advantage and disadvantage depending on the perspective. Unfortunately, the competitive advantage of the firm can not yet determine due to the new enterprises, and the generic strategy generates from Classical environment. According to the framework from IMD, there is an insight of strategy palette, is divided into four types classical environment, adaptive environment, visionary environment, and shaping environment. Most likely, the competitive advantage of XYZ is shaping the environment.

According to analysis and calculation indicate that whole scenario resulting in investment feasible from a financial perspective. From the tenant perspective, the result of the Discounted Payback period indicates that the investment will break even at $9^{\text {th }}$ year. The Present Net Value for Alternative 1 and Alternative 3 have a little deviation with Alternative 1 show the highest with Rp. 4,506 trilion and the Alternative 2 only Rp. 3,63 trillion. However, in Profitability Perspective, Alternative 2 shows the highest with 15,81; meanwhile, the least is Alternative 1 with 10,17. The sequence also followed from Internal Rate of Return with Alternative two $27,68 \%$. This condition occurred because Alternative 2 and 3 have the portion of debt and resulting leverage to the assessment. Based on those result, Alternative 2 is a favorable scenario because the tenant only invests half from the total investment and get a higher return.

From the XYZ perspective, almost the result of feasibility financial assessment indicates that the number of Payback Period, Discounted Payback Period, Net Present Value, Profitability Index, and Internal Rate of Return is similar. It occurred due to the source of funding is full from equity, and the favorable scenario is Alternative 1. Unfortunately, since the feasibility financial assessment of XYZ depends on tenant analysis, so the possibility is Alternative 2 either.

Since the model exposes of assumption and judgment so the sensitivity analysis should be conduct, it consists of several parameters that relate with volatility like the amount of investment that relates to Capital Expenditure, Cost of Revenue, Revenue, General and Administration Expenses, Interest rate and cost of capital. For the Capital Expenditure, Cost of Revenue and General \& Administration Expenses resulting directly proportional for both swing (+/-). Only the fluctuation of Revenue + Cost of Revenue and cost of capital indicate higher disparation between two sign (+/-). The business scheme that XYZ can adopt is Joint Venture Agreement, and it generates from the Analytical Hierarchy Process with weighing 37,74\% highest compared to other option such as Build Operate Transfer and Kerja Sama Pengusahaan. 


\section{RECOMMENDATION}

Since the XYZ need another revenue stream beside aero revenue, the non-aero revenue is necessary. However, the model is only a plan, even though it consists of several scenarios and alternative the execution is critical of this matter. The firm also has the limitation of the funding, the worst condition of the investment if no partner agree to operate the business it will jeopardize the firm. So there another option to fund the infrastructure is using the Viability Gap Fund (VGP), its like the instrument financial tool that provides by the government for Public-Private Partnership (PPP). VGP supports the investment that as financially feasible but in the source of fund limitation, since the initial investment of XYZ is Rp. 188.647.712.794 which over the requirement ( $>$ Rp. 100 billion). So with the incentive of the fund, the potential developer will attract the investment because the liabilities decrease. Beside the VGP XYZ also can conduct the cashback system to the tenant, so the tenant beside build their infrastructure they also construct the supporting facilities like road, bridge, utilities, etc. and after several years XYZ can return the investment to the tenant. Both of tenant and XYZ also should conduct risk management to prevent and minimize risk that may expose to the investment.

\section{REFERENCES}

Abisay, Terry George.2013. Manajemen Risiko Pada Bandara Soekarno Hatta Berbasis ISO 31000. Jurnal Teknik Industri, Vol.14 No.2.

Agustina, Meidita. Soekarno, Subiakto. 2012. Financial Performance Assessment of PT Angkasa Pura II in Comparison with other Airport Company Locally and Globally. Journal of Business and Management Vol 1, No.5 318-331.

Angkasa Pura II. 2017. 2015-2017 Annual Report. Retrieved from http://www.angkasapura2.co.id/en/manajemen/laporan-tahunan

Badan Pengusahaan Batam. 2017. Financial Report BP Batam 2015-2017. Retrieved from https://bpbatam.go.id/ini/index.jsp

Bank of Indonesia. 2018. Historical Data BI 7-day Repo Rate. Retrieved from https://www.bi.go.id/en/moneter/bi7day-RR/data/Contents/Default.aspx Accessed 28 January 2019.

BPS Indonesia. 2017. Annual Report, 2017. Retrieved from https://www.bps.go.id/ Accessed 28 January 2019.

Creswell, JW.1994. Research Design Qualitative and Quantitative Approaches. Sage Publications. London

Das, Sourobh. 2017. What is a Business Model Canvas? Retrieved from https://www.feedough.com/businessmodel-canvas-explained/ Accessed 28 January 2019.

Dethirafuri, Raharsi. 2012. Krakatau Steel (A): Financial Performance. SBM IBCC. Bandung

Elsa, Felicia. 2018. Financial Feasibility Study of New Manufacturing Facility in China (Case Study: PT. Kue Enak). ITB. Bandung

Enterprise Risk Management-Integrated Framework. 2004. COSO. The Institute of Internal Auditors.

Fakhri, Rehan Aufa. 2018. Financial Feasibility Study and Public-Private Partnership Funding Alternatives for The Development Of New Port In Bulungan District, North Kalimantan Province. ITB. Bandung

Fasone, Vincenzo. 2016. Business performance of airports: Non-aviation revenue and their determinants. University of Enna. Italy

Thompson Jr, A. A., Strickland III, A. J., \& Gamble, J. E. 2008. Crafting \& Executing Strategy: The Quest for Competitive Advantage, McGraw Hill Education. England. 
Gitman, Lawrence J. 2012. Principles of Managerial Finance 13th Edition. Prentice Hall. Boston USA

Government of Indonesia. 2008. Undang-Undang No.36 Tahun 2008 Tentang Pajak Penghasilan

Government of Indonesia. 2017. Peraturan Menteri Keuangan No. 124/PM/010/2017 Tentang Sasaran Inflasi $2019,2020,2021$

Government of Indonesia. 2016. Peraturan Menteri Pekerjaan Umum dan Perumahan Rakyat No.05/PRT/M/2016 Tentang Izin Mendirikan Bangunan

Government of Indonesia. 2015. Peraturan Menteri Perhubungan No.43/2015 Tentang Konsesi dan Bentuk Kerjasama Lainnya

Government of Indonesia. 2008. Peraturan Pemerintah No.1/2008 Tentang Investasi Pemerintah dengan Swasta

Government of Indonesia. 2013. Peraturan Presiden No 66/2013 Tentang Percepatan Penyediaan Infrastruktur

Hodges, Michael A.2007. The Value of an Airport Business Plan. Henry Stewart Publication 1750-1938.

In, S. Y., Casemiro, L., \& Kim, M. J., (2017) A Decision Framework for Successful Private Participation in the Airport Sector, Journal of Air Transport Management. Volume 62, Pages 217-225

Ishikura, T., Sugimura, Y., \& Ishii, M. (2005). Fiscal characteristics of Incheon International Airport and Kansai International Airport. In Proceedings of the Eastern Asia Society for Transportation Studies Vol. 5, pp. 520-532.

Kalakou, Sofia. An Innovative Framework for the Study and Structure of Airport Business Models. Universidade de Lisbon. Portugal.

Kementerian Keuangan Republik Indonesia. 2018. APBN 2018. Retrieved from https://www.kemenkeu.go.id/apbn2018 Accessed 28 January 2019.

Komite Percepatan Penyediaan Infrastruktur Prioritas. 2018. Pembangunan Baru Bandara. Retrieved from https://kppip.go.id/proyek-strategis-nasional/f-proyek-pembangunan-bandar-udara-baru/pembangunanbaru-bandara-kertajati/ Accessed 28 January 2019.

Kumar, Arun. Sharma, Rachana.1998. Financial Management Theory and Practice. Atlantic Publishers. New Delhi

Merrill Lynch. 1997. Article How to Read A Financial Report

Merrill Lynch. 1997. Merrill Lynch Article How to Read A Financial Report

Nixon, Chad.2014. The Dynamic Planning Approach and the Death of the Traditional Master Plan. Henry Stewart Publication 1750-1946.

Osterwalder, Alexander. 2010. Business Model Generation: A Handbook for Visionaries, Game Changers, and Challengers. ISBN 978-0-470-87641-1 Wiley.USA

Priyanto, S., Suharno, H., \& Haryono, H. (2016). Value Engineering Dan Strategi Bisnis Pada PT Angkasa Pura II. Jurnal Manajemen Transportasi dan Logistik, Vol. 3, Issue 2, pp. 245-257.

Putri, Nurul Sandy. 2018. Financial Feasibility Study of Mix Use Building Area Investment Plan. ITB. Bandung

PT BIJB (Perseroda). 2017. 2015-2017 annual report. Retrieved from https://bijb.co.id/downloads/ Accessed 28 January 2019.

PWC. 2015. PWC Report: Connectivity and growth Issues and challenges for airport investment. 
Retrieved from https://www.pwc.com/gx/en/capital-projects-infrastructure/publications/assets/connectivitygrowth-airport-investment.pdf Accessed 28 January 2019.

Reuters. 2018. Plaza Indonesia Realty Tbk Financial Highlights. Retrieved from https://www.reuters.com/finance/stocks/financial-highlights/PLIN.JK Accessed 28 January 2019.

Saaty, Thomas L.2008. Decision Making with the Analytical Hierarchy Process. University of Pittsburgh. International Journal Services Sciences, Vol 1 No.1 2008. USA.

Skaptadóttir. Hrönn. 2016. Financial Assessment and Risk Analysis for Airport Hotel. Rejkjavik University. Iceland.

Skytrax. 2016. The World's Top 100 Airports 2016. Retrieved from https://www.worldairportawards.com/theworlds-top-100-airports-2016/ Accessed 28 January 2019.

Surachman, Eko Nur. 2014. Dana Dukungan Tunai Infrastruktur (Viability Gap Fund): Harapan Baru Pembangunan Infrastruktur di Indonesia. Kementeriaan Keuangan Republik Indonesia 2014.

Vidovic, Andrija and Co.2017. Mostar Airport Strategic Development Model. University of Zagreb. Croatia.

World Airport Codes. 2018. World Top 30 Busiest Airport in the world 2018. Retrieved from https://www.worldairport-codes.com/world-top-30-airports.html Accessed 28 January 2019.

Yahoo Finance. 2018. Historical Data of JKSE Index. Retrieved from https://finance.yahoo.com/quote/\%5EJKSE/history?period1=1356973200\&period2=1543338000\&interva l=1wk\&filter=history\&frequency=1 wk Accessed 28 January 2019.

Yuliawati, Eny. 2017. West Java International Airport and The Potential of Kertajati as The Aerocity. Retrieved fromhttps://www.researchgate.net/publication/318881448_Bandar_Udara_Internasional_Jawa_Barat_BIJ B_dan_Potensi_Kertajati_Sebagai_Aerocity Accessed 28 January 2019. 